\title{
Biofertilizantes no controle da mancha bacteriana (Xanthomonas spp.) do tomateiro
}

\author{
Vinícius William Borges Rodrigues ${ }^{1}$, Thays Vieira Bueno ${ }^{1}$, Nilvanira Donizete Tebaldi ${ }^{2}$
}

${ }^{1}$ Graduando em Agronomia, ${ }^{2}$ Professora Adjunto, do Instituto de Ciências Agrárias, Universidade Federal de Uberlândia, Av. Amazonas s/n, Bloco 2E-121, Campus Umuarama, CEP 38.400-902, Uberlândia, MG, Brazil

Autor para correspondência: Nilvanira Donizete Tebaldi (nilvanira@iciag.ufu.br)

Data de chegada: 29/04/2015. Aceito para publicação em: 28/08/2015.

$10.1590 / 0100-5405 / 2094$

\section{RESUMO}

Rodrigues, V. W. B.; Bueno, T. V., Tebaldi, N. D. Bioferilizantes no controle da mancha bacteriana (Xanthomonas spp.) do tomateiro. Summa Phytopathologica, v.42, n.1, p.94-96, 2016.

A mancha bacteriana do tomateiro, causada por quatro espécies de Xanthomonas pode provocar perdas significativas na produção da cultura e a utilização de biofertilizantes na proteção de plantas tende a reduzir a incidência de doenças. O objetivo do trabalho foi avaliar o efeito dos biofertilizantes no controle preventivo e curativo da mancha bacteriana do tomateiro. Para o controle preventivo da doença, plantas de tomate cultivar Santa Cruz Kada, com 3 a 4 folhas foram pulverizadas com os biofertilizantes (Soil-Set, Agro-Mos e Cop-R-Quick) e água (testemunha); e dois dias após foram inoculadas por aspersão com a suspensão bacteriana nas concentrações $10^{9} \mathrm{UFC} \mathrm{mL} \mathrm{mL}^{-1}\left(\mathrm{OD}_{550}=0,5\right)$ e $10^{6} \mathrm{UFC} \mathrm{mL} \mathrm{mL}^{-1}$, com o isolado UFU A35 de Xanthomonas sp. Para o controle curativo, as plantas foram inoculadas com a suspensão bacteriana, e dois dias após foram pulverizadas com os biofertilizantes e água. A severidade da mancha bacteriana foi avaliada usando uma escala diagramática; aos 3, 5, 8, 11 e 14 dias após a inoculação e calculada a área abaixo da curva de progresso de doença (AACPD). O controle preventivo foi mais eficiente no manejo da mancha bacteriana do tomateiro, e os diferentes biofertilizantes reduziram a severidade da doença.

Palavras-chave: Solanum lycopersicum, Xanthomonas euvesicatoria, X. gardneri, X. perforans, X. vesicatoria.

\section{ABSTRACT}

Rodrigues, V.W.B.; Bueno, T.V., Tebaldi, N.D. Biofertilizers in the control of tomato bacterial spot (Xanthomonas spp.). Summa Phytopathologica, v.42, n.1, p.94-96, 2016.

Tomato bacterial leaf spot, caused by four Xanthomonas species, can induce significant losses in the culture, and the use of biofertilizers in the protection of plants tends to reduce the incidence of diseases. The aim of this study was to evaluate the effect of biofertilizers in the preventive and healing control of tomato bacterial leaf spot. For the preventive control of the disease, tomato plants cv. Santa Cruz Kada, with 3 or 4 leaves, were sprayed with biofertilizers (Soil-Set, Agro-Mos and Cop-R-Quick) and water (control); after two days, plants were inoculated by spraying the bacterial suspension at the concentrations of $10^{9} \mathrm{CFU}$
$\mathrm{mL}^{-1}\left(\mathrm{OD}_{550}=0.5\right)$ and $10^{6} \mathrm{CFU} \mathrm{mL}^{-1}$, using the isolate UFU A35 of Xanthomonas $\mathrm{sp}$. For the healing control, plants were inoculated with the bacterial suspension and, two days later, plants were sprayed with the biofertilazers and water. The severity of bacterial leaf spot was evaluated by using a diagrammatic scale, at $3,5,8,11$ and 14 days after inoculation, and the area under the disease progress curve (AUDPC) was calculated. Preventive control was more efficient in the management of tomato bacterial leaf spot, and the different biofertilizers reduced the disease severity.

Keywords: Solanum lycopersicum, Xanthomonas euvesicatoria, X. gardneri, X. perforans, X. vesicatoria.

A mancha bacteriana do tomateiro é causada por quatro espécies do gênero Xanthomonas: Xanthomonas euvesicatoria, X. vesicatoria, $X$. gardneri e $X$. perforans (4). A doença ocorre frequentemente, sendo destrutiva em condições de elevada umidade, precipitação e temperatura entre 20 e $30^{\circ} \mathrm{C}(6)$.

Devido a pouca disponibilidade de produtos, o controle químico da bactéria tem sido feito com antibióticos e produtos à base de cobre (8) e o uso de biofertilizantes líquidos, na forma de fermentados microbianos enriquecidos, pode ser uma forma alternativa de controle de doenças, devido à ativação do metabolismo enzimático da planta (9). O biofertilizante Agrobio inibiu o crescimento de Xanthomonas euvesicatoria, sendo viável para o controle da mancha bacteriana do pimentão (2).

Assim, o objetivo deste trabalho foi avaliar diferentes biofertilizantes no controle preventivo e curativo da mancha bacteriana do tomateiro, em casa de vegetação.
O experimento foi conduzido no Instituto de Ciências Agrárias da Universidade Federal de Uberlândia - MG, no ano de 2013. O isolado UFU A35 de Xanthomonas sp. pertencente à coleção de trabalho foi cultivado em meio de cultura 523. Após $48 \mathrm{~h}$ foi preparada uma suspensão bacteriana em solução de $\mathrm{NaCl} 0,85 \%$ e ajustada em espectrofotômetro para $\mathrm{OD}_{550}=0,5\left(1 \times 10^{9} \mathrm{UFC} \mathrm{mL}^{-1}\right)$.

Em casa de vegetação, o ensaio foi realizado duas vezes, onde plantas de tomate cv. Santa Cruz Kada foram cultivadas em vasos com capacidade de $500 \mathrm{~mL}$, com substrato solo, areia, húmus e vermiculita (4:1:1:1). Após 15 dias da semeadura, as plantas (três a quatro folhas), no controle preventivo foram pulverizadas até o ponto de escorrimento com os biofertilizantes Agro-Mos (1,5 $\left.\mathrm{mL} \mathrm{L}^{-1}\right)$, Cop-R-Quik $(0,5$ $\left.\mathrm{mL} \mathrm{L}^{-1}\right)$ e Soil Set $\left(1,5 \mathrm{~mL} \mathrm{~L}^{-1}\right)$, e água, e dois dias após as plantas foram inoculadas via pulverização das folhas, com as suspensões nas concentrações de $10^{9}$ ou $10^{6}$ UFC.mL $L^{-1}$. No controle curativo, as plantas foram inoculadas com suspensões bacterianas descritas anteriormente, 
e dois dias após foram pulverizadas com a os biofertilizantes e água. Plantas pulverizadas com água foram consideradas as testemunhas. As plantas foram mantidas em câmara úmida 24 horas antes e após a inoculação.

$\mathrm{O}$ experimento foi em esquema fatorial, composto de 2 controles (preventivo e curativo), 4 produtos (3 biofertilizantes e a água), 2 concentrações da suspensão bacteriana $\left(10^{9}\right.$ e $10^{6}$ UFC. $\left.\mathrm{mL}^{-1}\right)$, com quatro repetições, sendo considerado como unidade experimental, um vaso contendo duas plantas.

A severidade da doença foi avaliada empregando-se a escala diagramática (7), aos 3, 5, 8, 11, 14 e 17 dias após a inoculação.

A Área Abaixo da Curva de Progresso de Doença (AACPD) foi calculada pela fórmula: AACPD $=\sum\left(\left(\mathrm{Y}_{\mathrm{i}}+\mathrm{Y}_{\mathrm{i}+1}\right) / 2\right)\left(\mathrm{t}_{\mathrm{i}+1}-\mathrm{t}_{\mathrm{i}}\right)$, onde: Y é a intensidade da doença (nota atribuída de acordo com a escala diagramática usada); t é o tempo (intervalo entre as avaliações, em dias); e i representa o número de avaliações no tempo (1). Os dados obtidos foram submetidos à análise de variância e as médias foram comparadas pelo teste de Tukey a $5 \%$ de significância.

Para a área abaixo da curva de progresso da doença (AACPD), na concentração do inóculo a $10^{6} \mathrm{UFC} \mathrm{mL}^{-1}$ (Tabela 1) não houve diferença significativa entre os controles curativo $(16,43)$ e preventivo $(15,06)$. $\mathrm{Na}$ concentração do inóculo a $10^{9} \mathrm{UFC}$. $\mathrm{mL}^{-1}$ a quantidade de doença do controle preventivo $(29,25)$ foi menor que o controle curativo $(33,06)$ diferindo significativamente entre si. O controle preventivo médio $(22,15)$ demostrou menor área abaixo da curva de progresso da doença, quando comparado à média do controle curativo $(24,75)$, para as plantas pulverizadas com os diferentes biofertilizantes e inoculadas com a bactéria Xanthomonas sp. Neste sentido, o controle preventivo da doença, independente do biofertilizante, torna-se uma medida de manejo da mancha bacteriana do tomateiro. A concentração do inóculo $10^{6} \mathrm{UFC} \mathrm{mL}^{-1}$ média $(15,75)$ diferiu significativamente da concentração do inóculo $10^{9} \mathrm{UFC} \mathrm{mL}^{-1}(31,15)$, fato já esperado, resultando em maior quantidade de doença nesta última concentração.

$\mathrm{Na}$ análise do desdobramento dos biofertilizantes dentro de cada concentração do inóculo (Tabela 2), quando se tem uma concentração elevada da suspensão bacteriana de $10^{9} \mathrm{UFC} \mathrm{mL}^{-1}$, o uso dos biofertilizantes Soil-Set $(27,0)$, Cop-R-Quik $(29,25)$ e Agro-Mos $(31,25)$ foi mais eficiente, reduzindo significativamente a quantidade de doença, quando comparado com as plantas pulverizadas com água $(37,12)$. No entanto, as plantas inoculadas com a suspensão bacteriana $10^{6} \mathrm{UFC} \mathrm{mL}^{-1}$ não apresentaram diferenças estatísticas entre os biofertilizantes e a água, embora a ACPD tenha sido menor para as plantas pulverizadas com os biofertilizantes.

No controle preventivo (Tabela 3) da doença, a AACPD das plantas inoculadas com as suspensões bacterianas nas concentrações $10^{6} \mathrm{UFC}$ $\mathrm{mL}^{-1}$ e $10^{9}$ UFC.mL $\mathrm{mL}^{-1}$ não apresentaram diferença estatística entre os biofertilizantes e a água, assim como, no controle curativo com o uso

Tabela 1. Área abaixo da curva de progresso da mancha bacteriana do tomateiro, no controle preventivo e curativo da doença, em diferentes concentrações do inóculo. Uberlândia, MG, 2013.

\begin{tabular}{llll}
\hline \multicolumn{4}{l}{ Concentração do inóculo $\left(\mathrm{UFC} \mathrm{mL}^{-1}\right)$} \\
\hline Controle & $10^{6}$ & $10^{9}$ & Média \\
\hline Curativo & $16,43 \mathrm{a}$ & $33,06 \mathrm{~b}$ & $24,75 \mathrm{~b}$ \\
Preventivo & $15,06 \mathrm{a}$ & $29,25 \mathrm{a}$ & $22,15 \mathrm{a}$ \\
\hline Média & $15,75 \mathrm{~A}$ & $31,15 \mathrm{~B}$ & \\
\hline C.V. (\%) & 17,25 & & \\
\hline & \\
Médias seguidas por letras iguais minúsculas, na coluna e maiúsculas, na linha, não diferem \\
estatisticamente entre si, pelo teste de Tukey a 5\% de significância.
\end{tabular}

Tabela 2. Área abaixo da curva de progresso da mancha bacteriana do tomateiro, para os diferentes biofertilizantes, em diferentes concentrações do inóculo. Uberlândia, MG, 2013.

Concentração do inóculo (UFC mL $\mathrm{H}^{-1}$ )

\begin{tabular}{lll}
\hline Biofertilizantes & $10^{6}$ & $10^{9}$ \\
\hline Soil-Set & $14,37 \mathrm{a}$ & $27,00 \mathrm{a}$ \\
Cop-R-Quik & $15,25 \mathrm{a}$ & $29,25 \mathrm{a}$ \\
Agro-Mos & $15,62 \mathrm{a}$ & $31,25 \mathrm{a}$ \\
Água (testemunha) & $17,75 \mathrm{a}$ & $37,12 \mathrm{~b}$ \\
\hline C.V. (\%) & 17,25 & \\
\hline
\end{tabular}

Médias seguidas por letras iguais minúsculas, na coluna não diferem estatisticamente entre si, pelo teste de Tukey a5\% de significância.

Tabela 3. Área abaixo da curva de progresso da mancha bacteriana do tomateiro, no controle preventivo e curativo da doença, com diferentes biofertilizantes. Uberlândia, MG, 2013.

\begin{tabular}{lccccc}
\hline \multicolumn{5}{c}{ Controle } & \\
\cline { 2 - 5 } & \multicolumn{4}{c}{ Concentração do inóculo (UFC mL $\left.\mathrm{mL}^{-1}\right)$} \\
\cline { 2 - 5 } Biofertilizantes & $10^{6}$ & $10^{9}$ & $10^{6}$ & $10^{9}$ & Média \\
\hline Soil-Set & $13,00 \mathrm{aA}$ & $27,00 \mathrm{aB}$ & $15,75 \mathrm{aA}$ & $27,00 \mathrm{aB}$ & $20,69 \mathrm{a}$ \\
Cop-R-Quik & $16,25 \mathrm{aA}$ & $28,00 \mathrm{aB}$ & $14,25 \mathrm{aA}$ & $30,50 \mathrm{aB}$ & $22,25 \mathrm{a}$ \\
Agro-Mos & $13,75 \mathrm{aA}$ & $31,75 \mathrm{aB}$ & $17,50 \mathrm{aA}$ & $30,75 \mathrm{aB}$ & $23,44 \mathrm{a}$ \\
Água (testemunha) & $17,25 \mathrm{aA}$ & $30,25 \mathrm{aB}$ & $18,25 \mathrm{aA}$ & $44,00 \mathrm{bB}$ & $27,43 \mathrm{~b}$ \\
\hline CV (\%) & 17,25 & & & & \\
\hline
\end{tabular}

Médias seguidas por letras iguais minúsculas, na coluna e maiúsculas, na linha, dentro do controle, não diferem estatisticamente entre si pelo teste de Tukey a 5\% de significância.

da suspensão bacteriana na concentração $10^{6} \mathrm{UFC} \mathrm{mL}^{-1}$. No entanto, no controle curativo as plantas, quando inoculadas com suspensão bacteriana na concentração $10^{9} \mathrm{UFC} \mathrm{mL}^{-1}$ apresentaram diferença estatística entre biofertilizantes e a água $(44,0)$, assim como a AACPD média dos biofertilizantes. Portanto, o uso de biofertilizantes pode ser uma alternativa no manejo da mancha bacteriana do tomateiro, reduzindo a severidade da doença.

O uso do biofertilizante Agro-Mos reduziu a incidência de míldio (Plasmopara viticula) $(3,10)$ e oídio (Uncinula nector) (3) em videira, e reduziu o crescimento da lesão bacteriana (Xanthomonas axonopodis pv. passiflorae) em frutos de maracujá (5). Deleito et al. (2) também atribuíram a redução da mancha bacteriana em pimentão à indução de resistência do biofertilizante Agrobio.

De acordo com os resultados, o controle preventivo foi mais eficiente no manejo da mancha bacteriana do tomateiro, e os diferentes biofertilizantes reduziram a severidade da doença, podendo ser recomendados no manejo da doença, reduzindo o uso de agroquímicos e consequentemente o impacto ambiental.

\section{REFERÊNCIAS}

1. Campbell, C.L.; Madden, L.V. Introduction to plant disease epidemiology. New York: Jonh Wiley, 1990. 532 p.

2. Deleito, C.S.R.; Carmo, M.G.F.; Fernandes, M.C.A.; Abboud, A.C.S. Ação 
bacteriostática do biofertilizante Agrobio in vitro. Horticultura Brasileira, Brasília, v.23, n.2, p.281-284, 2005.

3. Gomes, E.C.S.; Perez, J.O.; Barbosa, J. Resistência induzida como componente do manejo de doenças da videira. Engenharia Ambiental, Espírito Santo do Pinhal, v.6, n.2, p.114-120, 2009.

4. Jones, J.B.; Lacy, G.H.; Bouzar, H.; Stall, R.E.; Schaad, N.W. Reclassification of the xanthomonads associated with bacterial spot disease of tomato and pepper. Systematic of Applied Microbiology, Amsterdam, v.27, n.6, p.755-762, 2004.

5. Junqueira, K.P. Resistência genética e métodos alternativos de controle da bacteriose do maracujazeiro causada por Xanthomonas axonopodis pv. passiflorae. 2010. 172p. Tese (Doutorado em Fitopatologia), Universidade de Brasília, Brasília.

6. Kurozawa, C.; Pavan, M.A. Doenças do tomateiro (Lycopersicon esculentum). In: Kimati, H.; Amorim, L.; Rezende, J.A.M.; Bergamin Filho, A.;
Camargo, L.E.A. Manual de fitopatologia: doenças das plantas cultivadas. 4.ed. São Paulo: Agronômica Ceres, 2005. v.2, p.607-626.

7. Mello, S.C.; Takatsu, A.; Lopes, C.A. Escala diagramática para avaliação da mancha-bacteriana do tomateiro. Fitopatologia Brasileira, Brasília, v.22, n.3, p.447-448, 1997.

8. Nascimento, A.R; Fernandes, P.M.F.; Borges, L.C.; Moita, A.W.; Quezado-Duval, A.M. Controle químico da mancha-bacteriana do tomate para processamento industrial em campo. Horticultura Brasileira, Brasília, v.31, n.1, p.15-24, 2013.

9. Rodolfo Júnior, F.; Cavalcante, L.F.; Buriti, E.S. Crescimento e produção do maracujazeiro-amarelo em solo com biofertilizantes e adubação mineral com NPK. Revista Caatinga, Mossoró, v.21, n.5, p.134-145, 2008.

10. Rosa, R.C.T.; Coelho, R.S.B.; Tavares, S.C.C.H.; Cavalcanti, V.A.L.B. Efeito de indutores no controle de míldio em Vitis labrusca. Summa Phytopathologica, Botucatu, v.33, n.1, p.68-73, 2007. 